Download

UDC 911.3

https://doi.org/10.

17721/2308-135X.2020.57.35-41

Illgar Mammadov Bakhtiyar Baku State University, Baku, Azerbaijan, e-mail:

ilqar.tobacco@mail.ru

\title{
INCREASING DIFFERENCES IN THE LEVEL OF SOCIO-ECONOMIC DEVELOPMENT OF THE WORLD AND MIGRATION PROCESSES
}

There are sharp differences in socio-economic and demographic development between countries located in different regions of the world. These differences are more pronounced between Western European countries, the United States, Canada, Japan, and developing countries. That is why there is a large influx of people around the world. Currently, the main immigration centres in the world are the United States, Canada, Australia and Western Europe. Migrants from regional conflicts are also widely involved in migration flows around the world. Their influx of Western European countries creates several issues. For this reason, the countries receiving foreign migrants pursue a strict migration policy.

Sources and methods of research. To carry out the analyses the economic and social geography of the world, including scientific-analyses in the area of demographic development has been used. The reports of the UN Population Fund and the International Organization for Migration plays a pivotal role in this area. The analysis in the article is carried out with the help of statistics, the historical-geographical study of areas, mathematical analysis, comparative analysis methods.

Scientific innovations and personal recommendation of the author. For the first time, the occurring migration processes in the world and their issues of dependence on the level of socio-economic the development has been analyzed in the article. Using scientific and statistical sources, the author conducted an analysis in this direction, identified the main regions 
of migration in the world, its relationship with demographic development, and defined its regulating methods. The analysis highlights that international migration is also increasing intensively as the differences in the level of development between the countries intensify.

Summary of the study. European countries, the United States, Canada, Japan and Australia ensure sustainable development through the effective use of their economic potential and financial and technical capabilities. Problems in the field of demographic development in these regions, weak population growth, labour source shortages and problems create the need to accept foreign migrants. In most Asian and African countries, natural growth is still high, economic growth is slow in the face of high population growth in a short period, and the number of workplaces is many times fewer than the number of able-bodied people. The weak economic potential of this group of countries is not able to maintain the demographic potential. As a result, people migrate from rural to urban areas. Along with, external migration is intensive.

National and ethnic conflicts, border disputes, civil wars, and socio-political instability in some parts of the world have led to the expulsion of millions from their native lands. According to the UN's data, $90 \%$ of international migrants migrate to other countries in search of work. Almost all countries of the world are involved in this process. At present, there are $232 \mathrm{mln}$. international migrants across the world and about half of them are concentrated in 10 countries. Countries that receive foreign migrants are forced to take serious measures to regulate it.

Results. Differences in socio-economic and demographic development between countries in different regions of the world are growing, and international migration is taking place. High levels of natural growth in Asia, Africa and Latin America, as well as conflicts in North Africa, the Middle East, are contributing to the increase in migration. For this reason, countries receiving foreign migrants have a migration policy to regulate and, in most cases, reduce it. Today, about half of the world's immigrants live in 10 countries.

Keywords: developed countries, developing countries, socio-economic development, demographic development, external migration, immigration, labour migration, migration policy, natural growth, immigration centres. 
References:

1. Butov V.I. Demografiya. (Demography). Moscow-Rostov-on Don: March 2003, 592 p. (in Russian).

2. Valenti D.I., Kvasha A.Y. Osnovi demografii. (The basics of demography). M.: Thought, 1989, 286 p. (in Russian).

3. Maksakovsky V.P. Geoqraficheskaya kartina mira. V 2 kniqax. Kniqa 1. Obsaya xarakteristika mira (Geographical picture of the world. In 2 book Book I. General characteristics of the world). Bustard, Moscow, 2008. (in Russian).

4. Maksakovsky V.P. Geoqraficheskaya kartina mira. V 2 kniqax. Kniqa 2. Regionalyaya xarakteristika mira. (Geographical picture of the world. In 2 book Book I. Regional characteristics of the world). Bustard, Moscow, 2009. (in Russian).

5. Economicheskaya I sochialnaya geographiya mira. (The economic and social geography of the world). Baku, 2019. 583 p. (in Azerbaijan). 
6. Eminov Z.N. Geographiya. (Geography). Baku, 2005.656 p. (in Azerbaijan).

7. Belorus I strain mira. Statisticheskiy sbornik. Nachianalniy Statisticheskiy Komitet Respubliki Belorus. (Belarus and countries of the world. Statistical Digest. National Statistical Committee of the Republic of Belarus). Minsk, 2016,.398 p. (in Russian).

8. Belorus I strain mira. Statisticheskiy sbornik. Nachianalniy Statisticheskiy Komitet Respubliki Belorus. (Belarus and world countries. Statistical Digest. National Statistical Committee of the Republic of Belarus). Minsk, 2018.338 p.). (in Russian).

9. Demograficheskiy Ejigodnik Rossii, 2016. Federalnaya Slujba Qosudarstvennoy Statistiki. (Demographic Yearbook of Russia, 2016. Federal State Statistics Service). Moscow, 2017, 265 p.. (in Russian).

10. Demograficheskiy Ejigodnik Respubliki Belorus, 2016. Nachianalniy Statisticheskiy Komitet Respubliki Belorus. (Demographic Yearbook of the Republic of Belarus, 2016. National Statistical Committee of the Republic of Belarus). Minsk, 2017.440 p. (in Russian). 
11. Naselenie Ukraini za 2016 g. Demograficheskiy Ejigodnik. Qosudarstvennaya Statisticheskaya Slujba Ukraini. (The population of Ukraine for 2016. Demographic Yearbook. State Statistical Service of Ukraine). Kyiv, 2017, 134 p. (in Russian).

12. Rossiya I strain mira - 2016. Statsbornik. Rosstat. (Russia and the world countries - 2016. Stat-report. Rosstat. M., 2016.379 p. (in Russian).

13. Annan K. Mejdunarodnaya migrachiya I razvitie: Doklad Generalnogo sekretaryz OON na sesii Generalnoy Assablei OON (International Migration and Development: Report of the UN Secretary-General at the UN General Assembly). New York, 2006.

14. World migration in numbers. The joint report by the UN Department of Economic Affairs and the OECD for a high-level dialogue on UN migration and development. October 3-4, 2013.

15. World Migration 2003: Managing Migration Challenges and Responses for People on the Move. Vol. 2. Geneva: IOM, 2003. P. 5. 
16. Migration in an Interconnections for Action: Report of the Global Commission on the International migration, Geneva: GCIM, 2005. P. 1.

17. Alisov N.I., Khorev B.S. Economicheskaya I sochialnaya geografiya mira. Obshiy obzor. (Economic and social geography of the world. general review) M, 2003, 704 p. (in Russian).

18. Ryazantsev S.V., Tkachenko M.F. Mirovoy rinok truda b mejdunarodnaya migrachiya. (World labour market and international migration). ZAO Publishing House "Economics". M., 2010, 303 p. (in Russian).

19. Migrachiya I migrachionnaya politika Rossiyskoy Federachii: Nauchniy doklad. (Migration and Migration Policy of the Russian Federation). Scientific report. Ed. S.V. Ryazantseva. 2011.167 p. (in Russian). 